\title{
PERANCANGAN ADD ON ORACLE CAMPUS SOLUTION MODUL ADMINISTRASI SKRIPSI PADA UNIVERSITAS XYZ (STUDI KASUS)
}

\author{
Natalia Limantara ${ }^{1}$, Triady Bunawan ${ }^{2}$, Subob Hadi Sugianto ${ }^{3}$, Michael Saputra ${ }^{4}$ \\ ${ }_{1,2,3,4}$ Program Studi Sistem Informasi, School of Information Systems, \\ Universitas Bina Nusantara \\ Jl. KH Syahdan No. 9, Kemanggisan, Jakarta Barat, 11480, Indonesia \\ Email :nlimantara@binus.ac.id,vegazeronos@gmail.com,michael.saputra@gmail.com, \\ bobbygitm@gmail.com
}

\begin{abstract}
ABSTRAK
Penelitian ini akan menjelaskan mengenai proses pengembangan add on pada sistem ERP Oracle Campus Solutin untuk modul administrasi Skripsi pada Universitas XYZ. Dimana modul ini diperlukan oleh universitas untuk mempermudah proses administrasi skripsi seperti persiapan pengumpulan berkas skripsi, penjadwalan sidang skripsi, dan pengumpulan berkas skripsi setelah sidang akhir. Metode pengembangan add on ini menggunakan system development life cycle untuk pengembangan sistem informasi. Metode pengumpulan data yang digunakan adalah wawancara dan observasi. Hasil dari penelitian ini adalah rancangan add on yang sesuai untuk pengelolaan administrasi skripsi di Universitas XYZ dan siap untuk diimplementasikan ke tahap berikutnya yaitu pemrograman. Dengan hasil rancangan ini diharapkan pengelolaan administrasi skripsi dilakukan melalui satu pintu saja dan mempermudah baik staff,dosen, dan mahasiswa mendapatkan informasi yangd dibutuhkan.
\end{abstract}

Kata Kunci-perancangan, add on, ERP, oracle campus solution, SDLC

ABSTRACT

This research explains about the add on development process on ERP Oracle Campus Solution for thesis administration module at XYZ University. The university uses this module to make the thesis administration easier, such as preparing for thesis collection, scheduling thesis defense, and collecting thesis after the final thesis defense. Methodology used for this add on development is system development life cycle for information system development. Data collection methods used for this research are interview and observation. The result of this research is an appropriate add on design for thesis administration at XYZ University and ready to be implemented to the next step, which is programming. This design is expected to make thesis administration done by only one way for the staff, lecturer, and students to get their needed information easier.

Keywords- design, add on, ERP, oracle campus solution, SDLC

\section{PENDAHULUAN}

Saat ini perusahaan mulai menerapkan Enterprise Resource Planning (ERP) di dalam bisnisnya untuk mendapatkan keunggulan dalam bersaing. Beberapa manfaat dari ERP yang ingin didapatkan oleh perusahaan adalah pengurangan biaya, mempercepat layanan kepada pelanggan, peningkatan produktivitas, pengelolaan sumber daya yang lebih baik, membantu 
untuk pengambilan keputusan, dan beberapa manfaat lainnya [1]. Sistem ERP saat ini mulai diimplementasi di universitas-universitas. Namun Universitas memiliki kondisi yang berbeda dengan perusahaan pada umumnya dan ERP digunakan untuk keperluan akademis. Selain itu penerapan ERP pada Universitas dapat meningkatkan layanan untuk para mahasiswa, dosen, dan staff [2].

Universitas XYZ, yang merupakan universitas swasta di Indonesia juga telah mulai menerapkan ERP untuk membantu mengelola proses akademiknya. Software ERP yang digunakan adalah Oracle Campus Solution. Oracle Campus Solution memiliki beberapa modul utama yaitu Enrollment dan Degree Planning, keuangan mahasiswa, Learning Management Integration, Mobile Campus, dan Oracle Campus Analytics. Universitas XYZ melakukan beberapa kustomisasi terhadapOracle Campus Solutionagar sesuai dengan prosedur yang berjalan di Universitas XYZ. Salah satu proses yang dilakukan adalah melakukan penyesuaian terhadap modul tugas akhir. Sebelum menerapkan Oracle Campus Solution, pengelolaan adminstrasi tugas akhir mahasiswa menggunakan perangkat lunak yang dikembangkan secara in-house dengan menggunakan bahasa pemrograman Visual Basic 6.0. Namun dengan seiring berkembanganya teknologi, sistem operasi yang digunakan saat ini sudah tidak mendukung lagi bahasa pemrograman ini, sehingga para staff menggunakan virtual machine agar tetap bisa mengakses program tersebut. Kondisi ini menghambat kinerja staff karena kesulitan dalam mengakses perangkat lunak yang digunakan.

Dengan latar belakang tersebut maka peneliti melakukan perancangan modul Tugas Akhir di Oracle Campus Solution dengan menambahkan beberapa user requirement baru yang belum dapat didukung oleh perangkat lunak yang saat ini digunakan. Dengan perancangan modul tugas akhir di Oracle Campus Solution ini akan dihasilkan rancangan add on yang membantu para staffkarena sistem informasi yang dirancang berbasis web sehingga tidak tergantung lagi pada sistem operasi yang digunakan. Rancangan ini juga akan siap untuk diimplementasikan ke tahapan berikut yaitu pemrograman sebelum diimplementasikan untuk operasional administrasi sidang skripsi.

\section{PENELITIAN TERKAIT}

ERP di dalam bidang pendidikan dikembangkan dengan tujuan untuk mendukung layanan administrasi dan akademik yang utama. Beberapa fungsi utama yang ada ada ERP untuk pendidikan adalah administrasi mahasiswa (prosedur pendaftaran, pengelolaan keuangan mahasiswa, data mahasiswa), manajemen sumber daya manusia, dan keuangan. Manfaat utama dari penerapan ERP di dalam universitas adalah [3]:

- Meningkatkan akses informasi untuk keperluan perencanaan dan pengelolaan institusi

- Meningkatkan layanan untuk dosen, mahasiswa, dan karyawan

- Mengurangi resiko bisnis

- Meningkatkan pendapatan dan mengurangi biaya untuk meningkatkan efisiensi

Untuk meningkatkan faktor keberhasilan dari implementasi ERP di dalam Universitas terdapat beberapa faktor penentu keberhasilan yang harus diperhatikan [4]. Koordinasi sumber daya yang ada dikarenakan sumber daya yang terlibat di dalam Universitas berasal dari berbagai latar belakang ilmu, sehingga dukungan dari manajemen dan senat sangat penting. Karena Universitas terdiri dari beberapa Jurusan yang memiliki standar operasional masing-masing, membuat standar operasional diantara Jurusan juga merupakan salah satu faktor penentu keberhasilan implementasi ERP. Meningkatkan intergrasi diantara aktivitas yang ada, meghindari adanya duplikasi data, meningkatkan budaya self service, membangun keahlian dan pengetahuan, dan komunikasi merupakan faktor penting lainnya. 
Selain itu peran Business Process Reengineering (BPR) juga harus diperhatikan, Universitas harus mau untuk menyesuaikan proses bisnisnya sehingga dapat mengadopsi fungsi ERP yang ada. Kustomisasi juga harus dihindari dikarenakan jika terlalu banyak kustomisasi yang dilakukan kemungkinan kegagalan implementasi semakin tinggi.

\section{DASAR TEORI}

SDLC adalah sebuah proses untuk menentukan bagaimana sebuah sistem informasi dapat mendukung kebutuhan aktivitas bisnis, merancang dan membangun sistem, hingga penyampaian kebutuhan tersebut kepada pengguna.Membangun sebuah sistem informasi dengan menggunaan SDLC akan berpatokan pada empat fase dasar yaitu perencanaan, analisis, perancangan, dan implementasi. Dimana setiap fase akan memiliki serangkaian tahapan dna menghasilkan output yang spesifik [5].
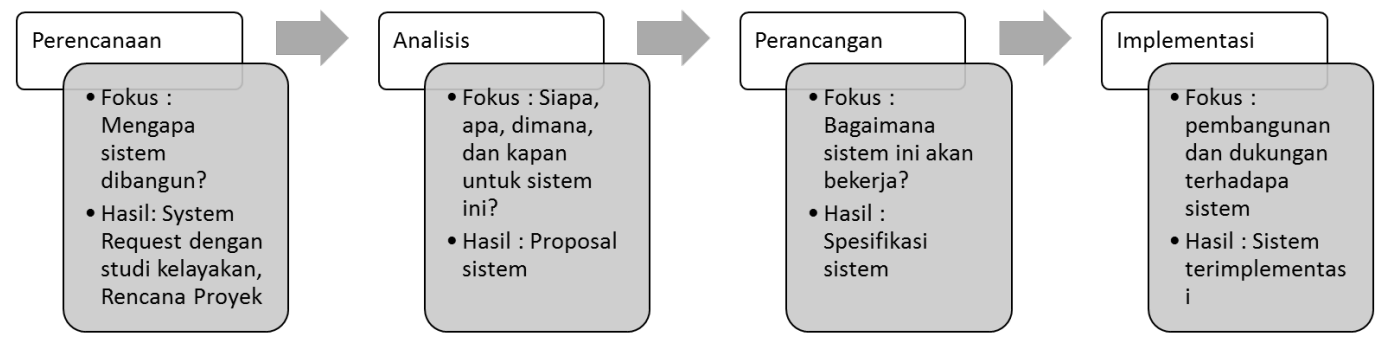

Gambar 1. System Development Life Cycle

\section{HASIL DAN PEMBAHASAN}

\subsection{Perencanaan}

Oracle Campus Solution yang telah digunakan oleh Universitas XYZ, belum dapat mengakomodir kebutuhan dalam hal administrasi Tugas Akhir mahasiswa. Sehingga proses yang terkait dengan skripsi masih ditangani oleh sistem lama. Kondisi ini membuat data menjadi tidak terintegrasi. Sebagai contoh, sebelum mengambil Tugas Akhir, mahasiswa diwajibkan untuk mengisi Kartu Rencana Studi (KRS) terlebih dahulu. Proses pengisian KRS sendiri telah dilaksanakan secara self services oleh mahasiswa melalu Oracle Campus Solution. Namun karena proses selanjutnya masih dilakukan oleh sistem lama, maka data dari Oracle Campus Solution harus dipindahkan ke sistem lama. Hal ini membuat proses menjadi tidak efisien.

Kondisi lain yang dihadapi adalah sistem lama dibangun menggunakan platform Visual Basic 6 dan Crystal Report. Sedangkan komputer yang digunakan oleh Universitas XYZ telah beralih ke sistem operasi Windows7 yang tidak lagi mendukung aplikasi yang dikembangkan dengan Visual Basic 6 dan Crystal Report. Sehingga untuk mengoperasikan sistem lama, staff Universitas XYZ memanfaatkan virtual machine di dalam komputernya. Yang menyebabkan pekerjaan menjadi terhambat.

Dengan kondisi tersebut, maka akan dikembangkan Add On di Oracle Campus Solution sehingga proses administrasi skripsi dapat dilaksanakan di satu tempat dan berbasis website. Dan add on ini juga menitiberatkan pada peningkatan layanan mandiri oleh dosen dan mahasiswa. Berikut adalah flowchart dari proses administrasi skripsi yang akan dijalankan di Oracle Campus Solution. 
Computatio: Journal of Computer Science and Information Systems, volume 1, no 2, Oktober 2017

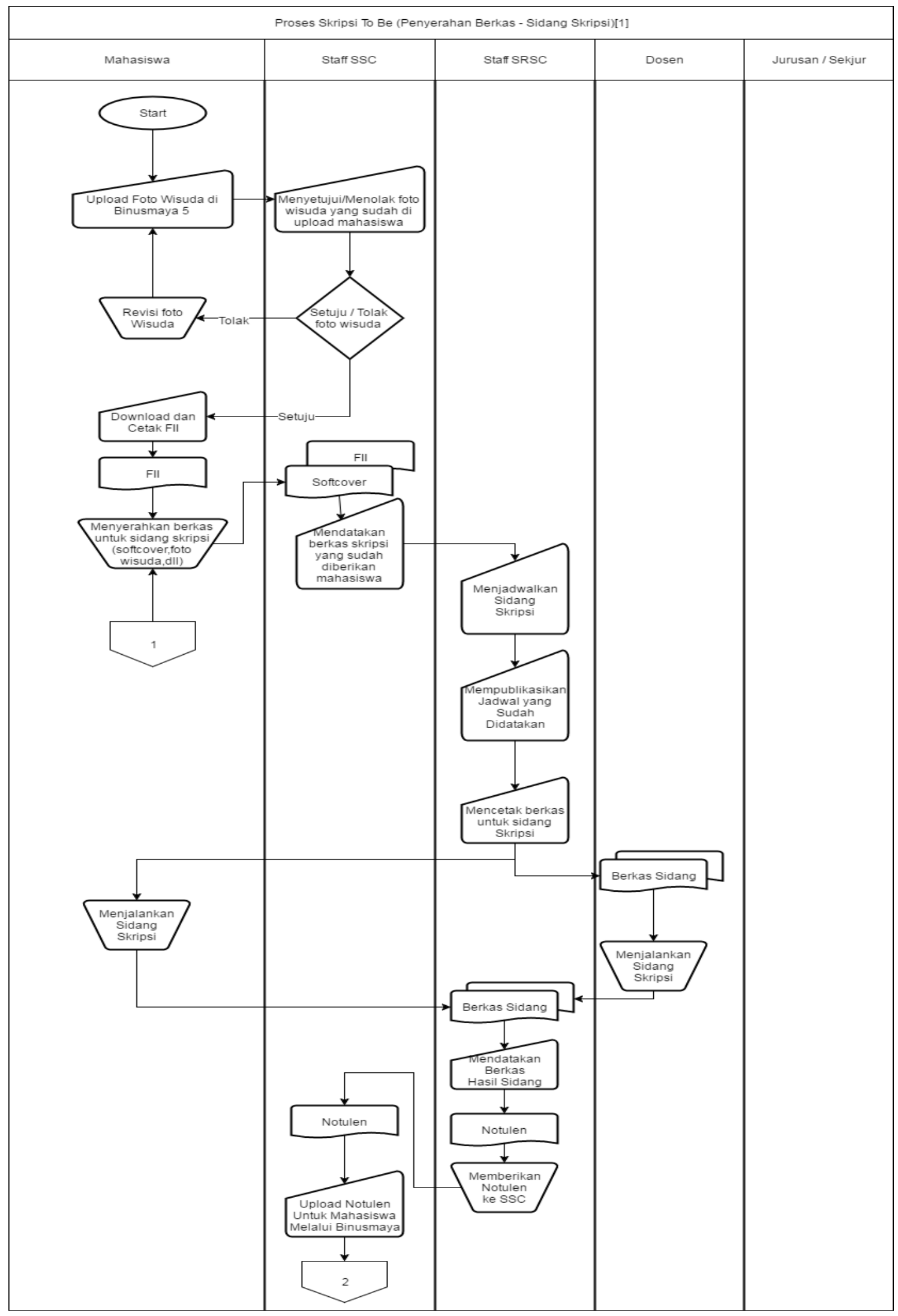

Gambar 2. Proses Bisnis Administrasi Skripsi (1) 


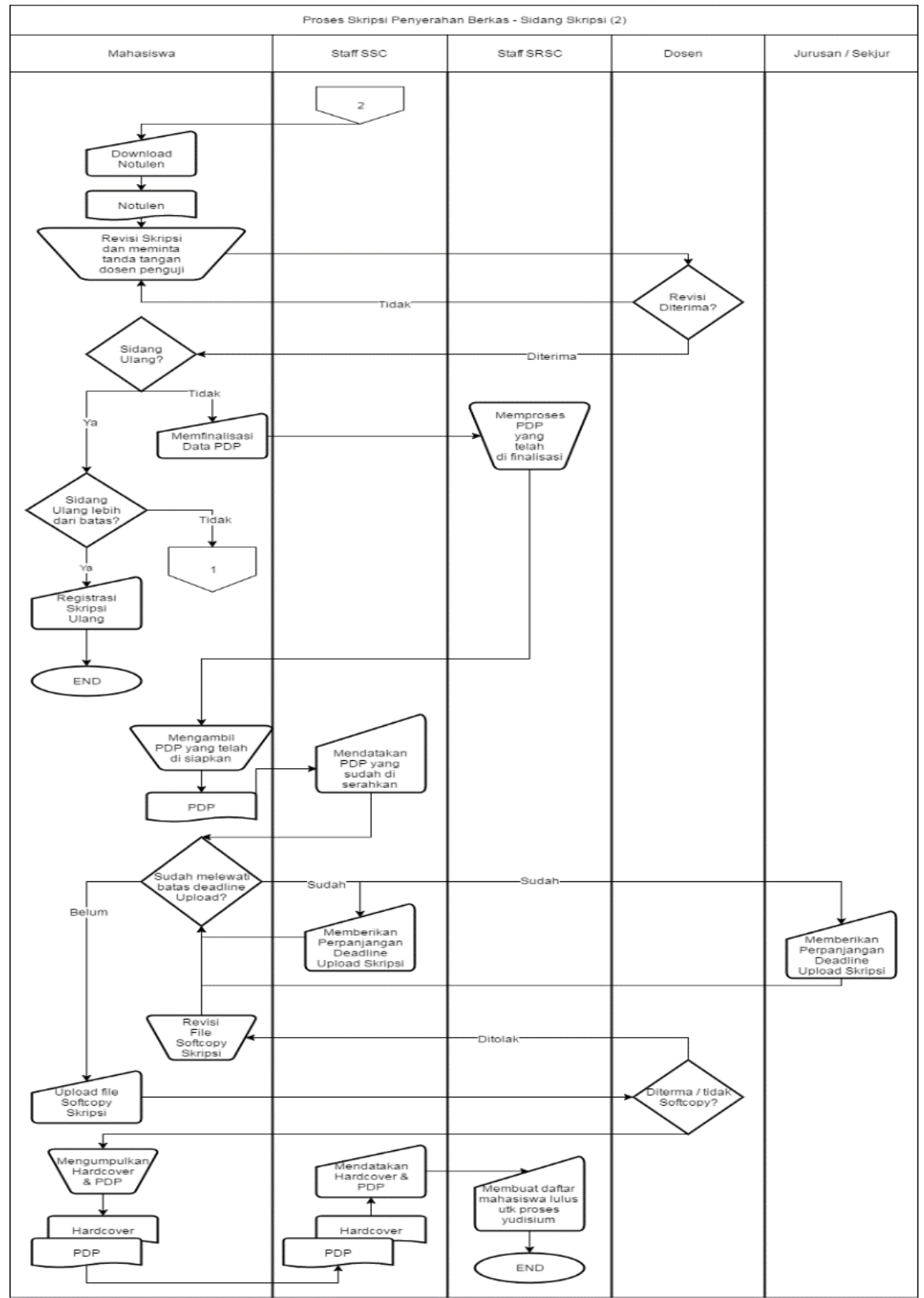

Gambar 3. Proses Bisnis Administrasi Skripsi (2)

\subsection{Analisis}

Add on Oracle Campus Solution untuk administrasi skripsi sendiri akan melibatkan beberapa pengguna, yaitu SRSC (Staff Registrasi Mahasiswa), SSC (staff layanan mahasiswa), mahasiswa, dosen, dan Sekertaris Jurusan. Masing-masing pengguna akan menggunakan portal yang dimiliki oleh Universitas XYZ untuk menjalankan fungsinya. Fungsi yang dapat diakomodir oleh Add On dari Oracle Campus Solution ini dapat dilihat pada gambar 4.

Beberapa proses akan dilakukan secara self service oleh mahasiswa dan dosen. Salah satu contohnya adalah dosen dapat melihat jadwal sidang langsung di portal Universitas. Mahasiswa juga dapat melakukan proses pengumpulan foto untuk Ijasah dan pengumpulan softcopy berkas skripsi langsung di Portal Mahasiswa. Dimana untuk Foto Ijasah staff SSC (Layanan Mahasiswa) cukup melakukan validasi apakah foto sudah sesuai standar dan untuk softcopy skripsi dosen akan melakukan validasi keabsahan dokumen melalui portal Universitas. 
Computatio: Journal of Computer Science and Information Systems, volume 1, no 2, Oktober 2017

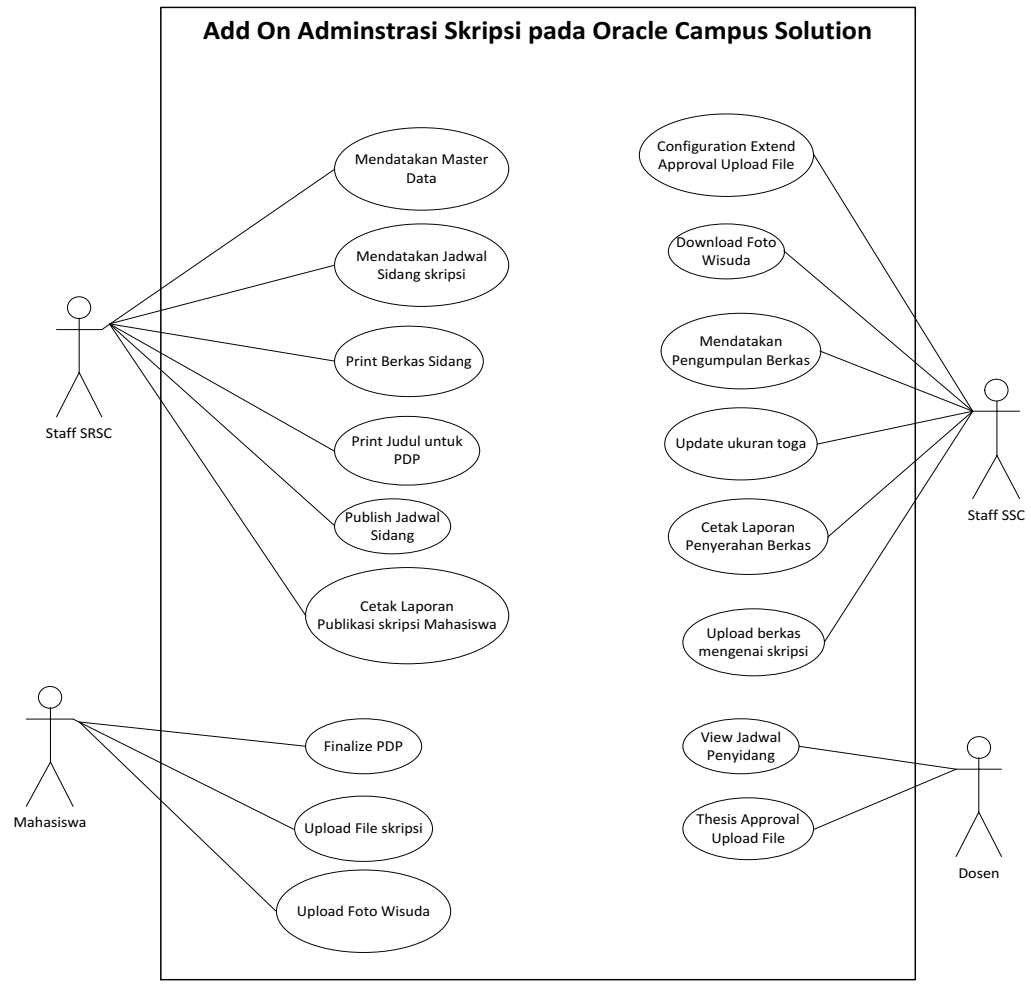

Gambar 4. Use Case Diagram

\subsection{Perancangan}

Add on Oracle Campus Solution ini akan diimplementasi pada portal Universitas sehingga semua pengguna akan mengakses fitur yang ada melalui satu tempat. Salah satu fitur Self Service pada Add on ini adalah mahasiswa dapat melakukan pengecekan data yang akan tertera pada Ijasah mereka melalui fitur Finalize PDP. Pada fitur ini mahasiswa dapat melihat informasi mengenai judul skripsi mereka dan jika telah sesuai mahasiswa dapat melakukan finalisasi.

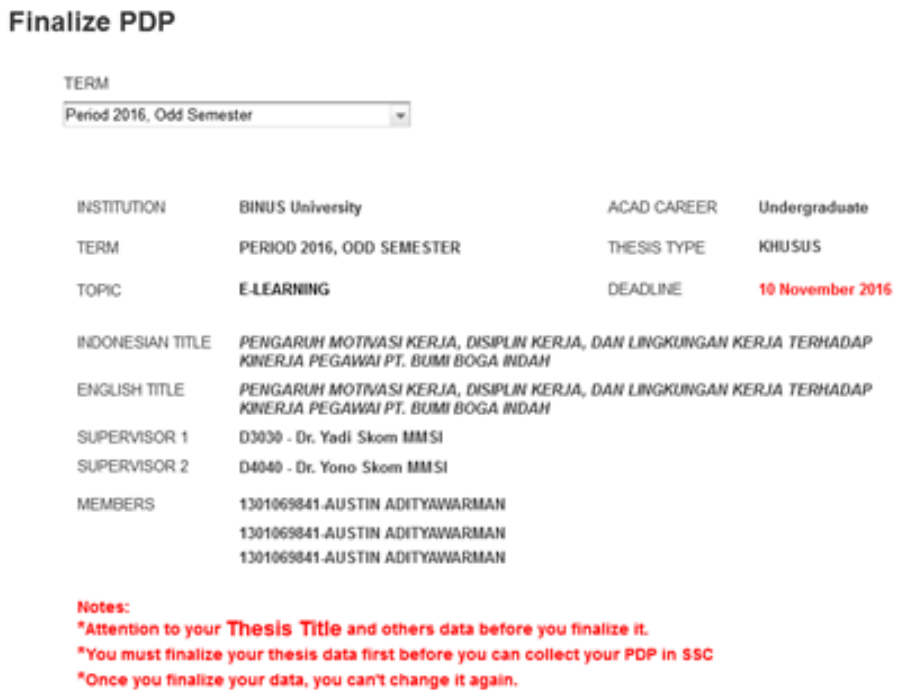

Gambar 5. Rancangan layar Finalize PDP oleh Mahasiswa 
Dengan adanya proses ini, maka Staff SSC( Layanan Mahasiswa) hanya tinggal melakukan pencetakan dokumen di atas Kop Surat Unviersitas, sehingga proses menjadi lebih cepat dan tingkat kesalahan juga berkurang. Proses lainnya adalah mahasiswa dapat melakukan upload file skripsi mereka dan dosen dapat melakukan finalisasi seperti yang tergambar pada gambar 6 dan gambar 7 .

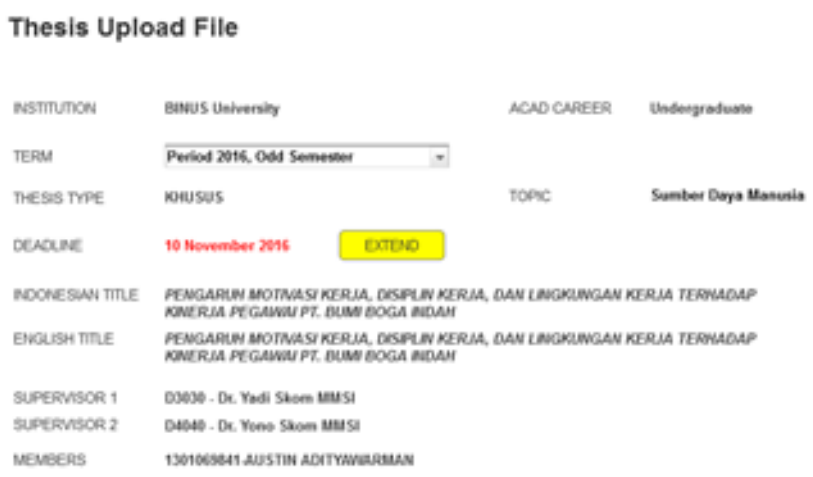

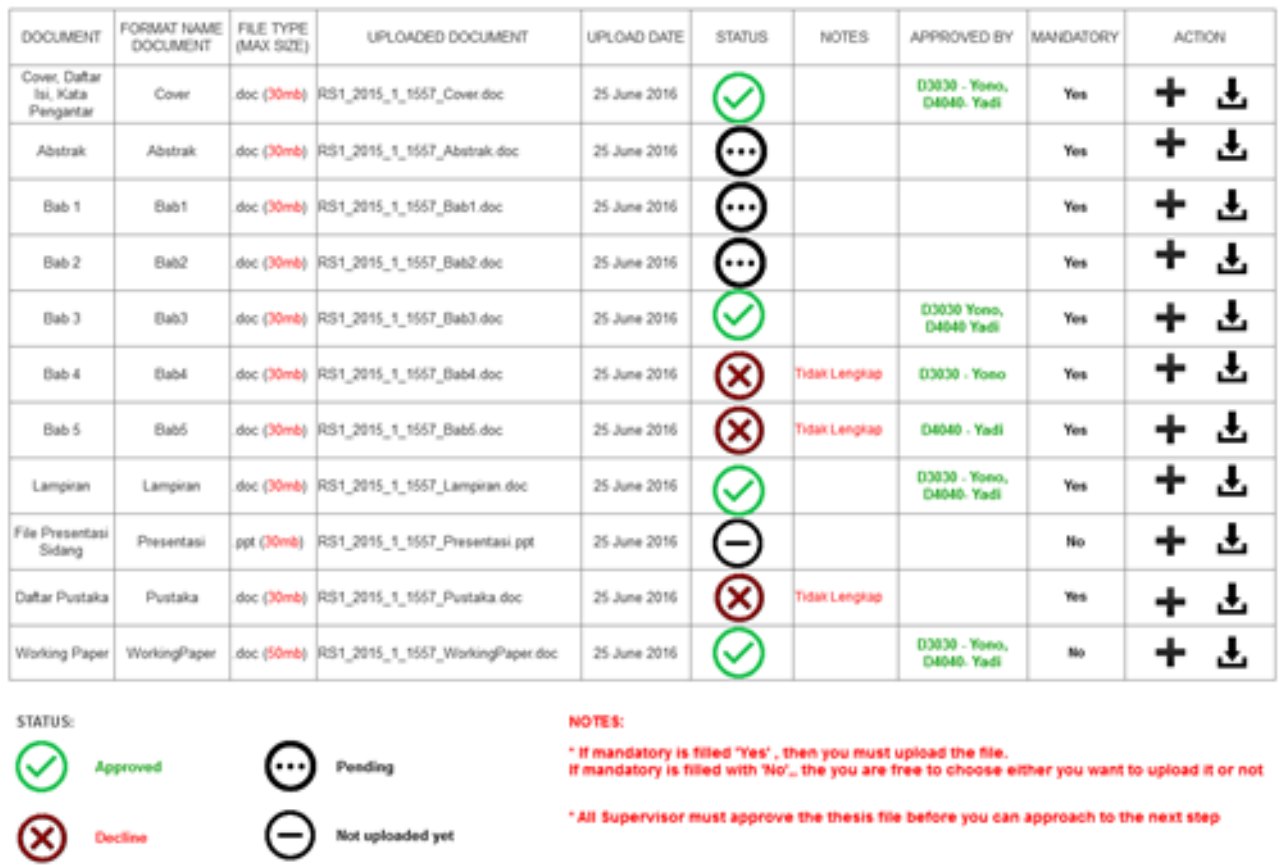

Gambar 6. Mahasiswa melakukan Upload File Skripsi 
Computatio: Journal of Computer Science and Information Systems, volume 1, no 2, Oktober 2017

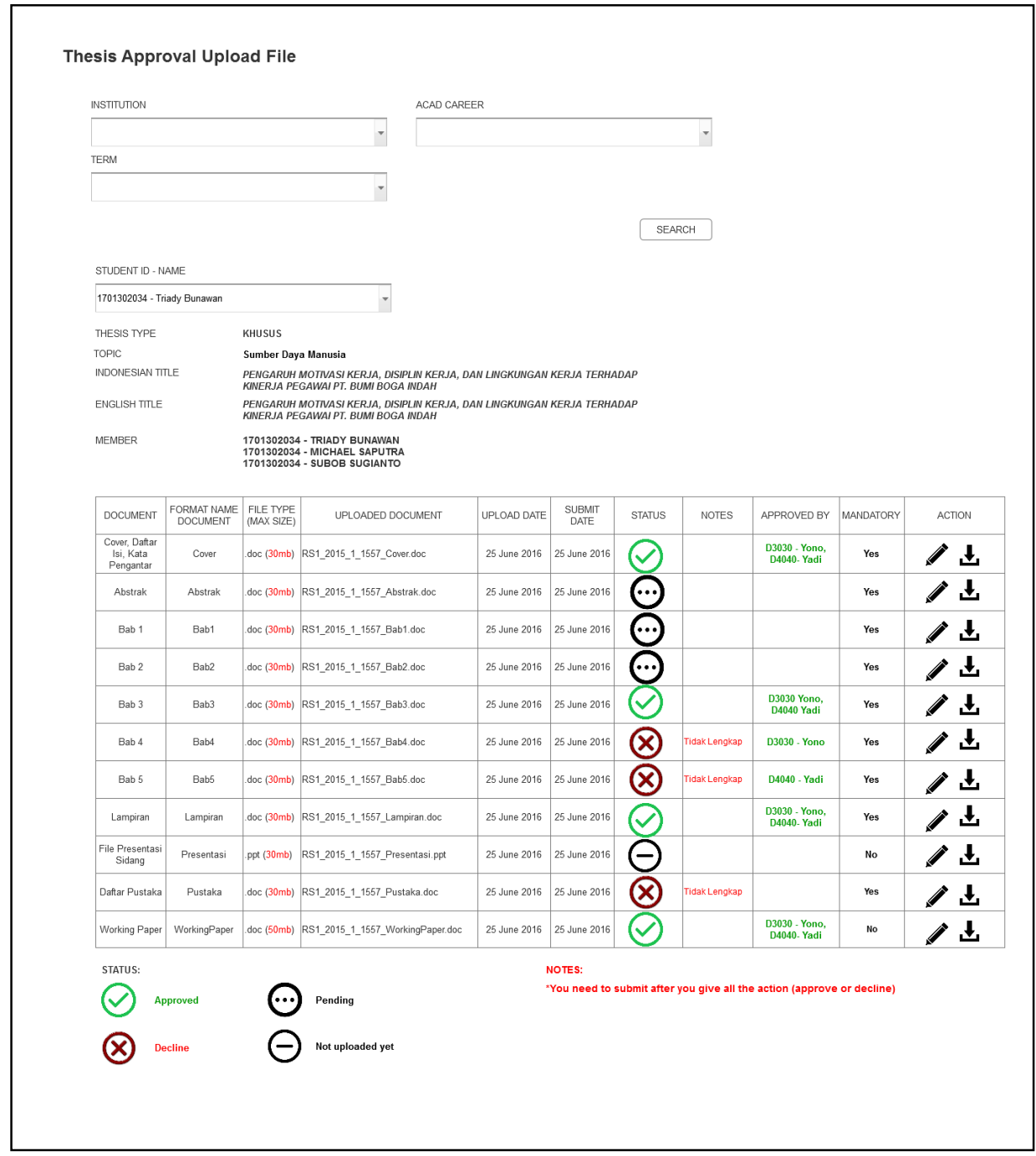

Gambar 7. Dosen Melakukan Approval File Skripsi Mahasiswa

\subsection{Implementasi}

Add on administrasi skripsi pada Oracle Campus Solution ini akan dikembangkan dengan infrastruktur Client Server. Dimana semua pengguna akan mengakses sistem informasi melalui portal Universitas melalui server aplikasi yang telah ada. Server Aplikasi ini akan berhubungan dengan database yang juga merupakan database yang diakses oleh Oracle Campus Solution.

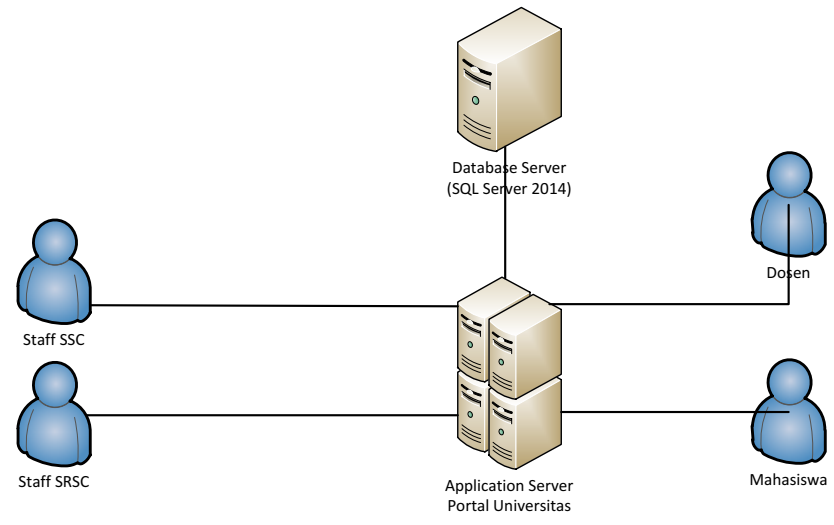

Gambar 8. Arsitektur Client Server 


\section{KESIMPULAN}

Berdasarkan pengembangan Add On Oracle Campus Solution modul Administrasi Skripsi, dapat disimpulkan :

1. Universitas XYZ mengalami kendala dalam hal mengelola administrasi skripsi karena sistem yang digunakan saat ini tidak lagi mensupport sistem operasi windows yang digunakan. Selain itu dengan diimplementasikannya Oracle Campus Solution menyebabkan data mahasiswa tersebar di beberapa aplikasi dan tidak saling terintegrasi.

2. Dari penelitian yang telah dilakukan dapat diambil sebuah kesimpulan jika Universitas XYZ harus melakukan pengembangan Add On untuk administrasi sidang yang dapat terhubung langsung dengan data yang ada di Oracle Campus Solution. Dengan Add On baik staff, mahasiwa, dan dosen dapat mengakses sistem informasi melalui satu pintu yaitu Portal Universitas.

3. Universitas XYZ juga mengembangkan beberapa proses bisnis menjadi self service di sisi dosen dan mahasiswa sehingga mengurangi beban administrasi di Staff Universitas dan mengurangi tingkat kesalahan dalam input data oleh Staff Universitas.

4. Diharapkan penelitian ini dapat dijadikan referensi untuk perancangan Add On pada Oracle Campus Solution sesuai dengan kebutuhan dari Universitas masing-masing.

\section{DAFTAR PUSTAKA}

[1] S. Shang and P. B. Seddon, "A Comprehensive Framework for Classifying the Benefits of ERP Systems," Am. Conf. Inf. Syst., pp. 1005-1014, 2000.

[2] A. Abugabah and L. Sanzogni, "Enterprise Resource Planning (ERP) System in Higher Education: A literature Review and Implications," Int. J. Hum. Soc. Sci., vol. 5, no. 6, pp. 395-399, 2010.

[3] L. Zornada and T. B. Velkavrh, "Implementing ERP systems in higher education institutions," in 27th International Conference on Information Technology Interfaces ITI 2005, 2005, pp. 307-313.

[4] R. M. T. R. L. Ahmad, "CAMPUS ERP IMPLEMENTATION FRAMEWORK FOR PRIVATE INSTITUTION OF HIGHER LEARNING ENVIRONMENT IN 2 ERP in Education," WSEAS Trans. Adv. Eng. Educ., vol. 8, no. 1, pp. 1-12, 2011.

[5] R. M. Roth, A. Dennis, and B. H. Wixom, System Analysis and Design, 5th ed. SIngapore: John Wiley \& Sons Singapore Pte. Ltd., 2013. 